\title{
Introduction: literary papers as the most "diasporic" of all archives
}

Book or Report Section

Published Version

Creative Commons: Attribution-Noncommercial-Share Alike 4.0

Open Access

(2018) Introduction: literary papers as the most "diasporic" of all archives. In: Sutton, D. C. and Livingstone, A. (eds.) The Future of Literary Archives: Diasporic and Dispersed Collections at Risk. ARC, pp. 1-14. ISBN 9781942401575 Available at https://centaur.reading.ac.uk/78011/

It is advisable to refer to the publisher's version if you intend to cite from the work. See Guidance on citing.

Publisher: ARC

All outputs in CentAUR are protected by Intellectual Property Rights law, including copyright law. Copyright and IPR is retained by the creators or other copyright holders. Terms and conditions for use of this material are defined in the End User Agreement.

\section{www.reading.ac.uk/centaur}

\section{CentAUR}

Central Archive at the University of Reading

Reading's research outputs online 
THE FUTURE OF LITERARY ARCHIVES 


\section{COLLECTION DEVELOPMENT, CULTURAL HERITAGE, AND DIGITAL HUMANITIES}

This series publishes both monographs and edited thematic collections in the broad areas of cultural heritage, digital humanities, collecting and collections, public history, and allied areas of applied humanities. In the spirit of our mission to take a stand for the humanities, this series illustrates humanities research keeping pace with technological innovation, globalization, and democratization. We value a variety of established, new, and diverse voices and topics in humanities research, and this series provides a platform for publishing the results of cutting-edge projects within these fields.

The aim is to illustrate the impact of humanities research and in particular reflect the exciting new networks developing between researchers and the cultural sector, including archives, libraries and museums, media and the arts, cultural memory and heritage institutions, festivals and tourism, and public history.

\section{Acquisitions Editor}

Danièle Cybulskie

\section{Evaluation and Peer Review}

The press has every proposal independently evaluated by expert reviews before any formal commitment is made by the press to the author. Further, all submitted manuscripts are subject to peer review by an expert chosen by the press. 


\title{
THE FUTURE OF LITERARY ARCHIVES: DIASPORIC AND DISPERSED COLLECTIONS AT RISK
}

\author{
Edited by
}

DAVID C. SUTTON with ANN LIVINGSTONE 


\section{British Library Cataloguing in Publication Data}

A catalogue record for this book is available from the British Library

\section{(C) 2018, Arc Humanities Press, Leeds}

cc) (i) $\fallingdotseq$ (5) This work is licensed under a Creative Commons Attribution-

NonCommercial- NoDerivatives 4.0 International Licence.

The author asserts their moral right to be identified as the author of their part of this work.

Permission to use brief excerpts from this work in scholarly and educational works is hereby granted provided that the source is acknowledged. Any use of material in this work that is an exception or limitation covered by Article 5 of the European Union's Copyright Directive (2001/29/EC) or would be determined to be "fair use" under Section 107 of the U.S. Copyright Act September 2010 Page 2 or that satisfies the conditions specified in Section 108 of the U.S. Copyright Act (17 USC §108, as revised by P.L. 94-553) does not require the Publisher's permission.

ISBN: 9781942401575

e-ISBN: 9781942401582

\section{https://arc-humanities.org}

Printed and bound by CPI Group (UK) Ltd, Croydon, CR0 4YY 


\section{INTRODUCTION: LITERARY PAPERS AS THE MOST “DIASPORIC” OF ALL ARCHIVES}

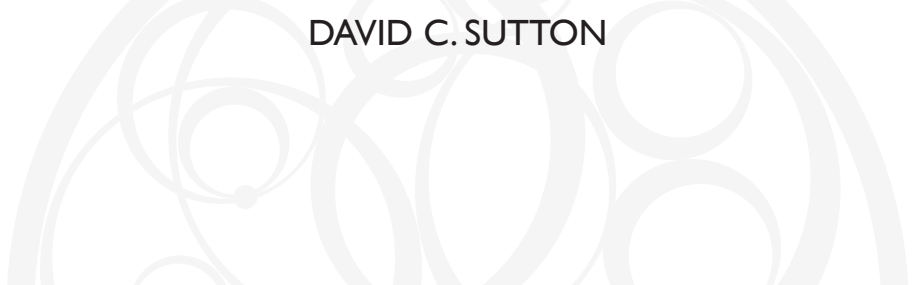

The essays collected in this book all derive or continue from the recent work of the Diasporic Literary Archives Network and illustrate the innovative and exciting range of programmes and actions which it generated. The Network was conceived and planned by a team of archivists, researchers and scholars in the University of Reading during 2010-2011, and came into existence on January 1, 2012, funded by a generous grant from the Leverhulme Trust. Although the Leverhulme Trust's financial support came to an end in 2015, the Network has continued many of its projects and activities in the subsequent years and retains a clear identity through ongoing cooperation between its members and through regular updating of its website.

From the beginning, the Network proposed to take a comparative, transnational and internationalist approach to studying literary manuscripts, their uses and their significance. It took as its prime starting point the notion that literary archives differ from most other types of archival papers in that their locations are more diverse and difficult to predict; they may have a higher financial value which will lead to their more frequently being purchased-as opposed to being deposited or donated; and acquiring institutions for literary papers have historically had very little by way of collecting policies. Consequently, the collecting of literary papers has often been opportunistic, unexplained and serendipitous.

The first points of comparison for this defining view of the unpredictable mobility of literary papers were the existing sections and the proposed future sections within the International Council on Archives. Using these benchmarks, assessments could be made in contrast with national and regional official papers; archives of local, municipal and territorial government; architectural archives; religious and faith tradition archives; archives of sports and games; political, business, and trade union archives; archives of educational institutions, hospitals, prisons, museums, and palaces; legal, notarial, and judicial papers; parliamentary and political papers; and the archives of international organizations. The comparisons 
confirmed that no category of archival material was more subject to uncertainty of location and to haphazardness of acquisition.

The question of how to define "literary" for these archival purposes preoccupied the Network much less than it had preoccupied predecessor projects. There was an early working consensus that our subject was the archival manuscripts, correspondence, and personal papers of poets, novelists, dramatists, literary essayists and critics, men and women of letters, biographers, and autobiographers. Our definition would not include journalists, theologians, philosophers, or politicians (even when, like Bertrand Russell or Winston Churchill, they had been awarded the Nobel Prize for Literature). The calm ease with which our set of definitions was deemed to be internationally acceptable contrasted with the reception accorded the Location Register of Twentieth-Century English Literary Manuscripts and Letters in the late 1980s and some of the distinctly bizarre criticism the Register received at that time:

Sir,

The correspondence about John Meade Falkner prompts me to note that the 100 volumes of Bishop Hensley Henson's journals, in the Dean and Chapter Library at Durham, are not listed in the Register. Was an atheist in charge?

Charles Welldon, Hazlemere

Letter to the London Review of Books, September 14, 1989

The choice of the dramatic term "diasporic" was a defining moment in the life-story of the Network. The established literature of racial, tribal, and national diasporas provided a philosophical framework which gave a highly original set of points of reference for the study of literary archives. Concepts such as the natural home, the appropriate location, exile, dissidence, fugitive existence, cultural hegemony, patrimony, heritage, and economic migration were deployed to provide new perspectives. The essential nature of literary manuscripts was scrutinized and certain key features proposed and reviewed. Early conclusions about this essential nature stressed the differentness of literary papers, and the vital importance of form as well as content:

Literary manuscripts are not like other archives. Their importance lies in who made them and how they were made, the unique relationship between author and evolving text, the insights they give into the act of creation. The supreme example of this magical combination of form and content is provided by the manuscripts of Marcel Proust, lovingly preserved in the Bibliothèque Nationale de France, 171 volumes of cross-hatched text, with later additions on small pieces of paper-the famous paperoles-glued onto almost every page: a wonderfully dreadful conservation challenge.

Literary archives often have a higher financial value than other archives. They are more likely to be found in libraries than in archives offices. In many countries of the world literary archives are housed in private foundations (such as the Fundação Casa de Rui Barbosa in Rio de Janeiro), in literary 
museums (such as the Museum of Japanese Modern Literature in Meguroku, Tokyo), or in literary houses (such as the Maison de Balzac in Paris). In countries such as the USA, Canada and the UK, university libraries play a leading role, but this is by no means true in all countries. In France, for example, public libraries (often in the author's home town) are the principal repositories, together with the Bibliothèque Nationale. In contrast with most other types of archives-business archives, medical archives, architectural archives, religious archives or municipal archives-literary archives are often scattered in diverse locations without any sense of appropriateness or "spirit of place."

Sutton, 2014, 295-96

In the course of the Network's discussions, some remarkable examples of diasporic literary archives emerged. A particular favourite was the literary archive developed by the Australian Defence Force Academy, one of the most important literary collections in Australia, which was created in order to help to broaden the outlooks of young people undergoing military training. A 1988 article by Graham Rowlands with the captivating title "On Selling Literary Papers to the Australian Defence Force Academy: I'd Just Be Perfect" is now easily found online (www.unsw.adfa.edu.au/ library/finding-aids/guide-papers-graham-rowlands).

The papers of J. R. R. Tolkien, including the manuscripts of The Lord of the Rings and The Hobbit, represent one of the best early examples of North American curators who were able to take advantage of their strong financial position, their freedom to acquire, and their literary knowledge. William B. Ready, Director of Libraries at the Marquette University in Milwaukee from 1956 to 1963, was an admirer of Tolkien and an important figure in a rising generation of US librarians and archivists who were prepared and permitted to follow their hunches and to purchase the papers of authors who were still alive, who were fairly young, and who were out of fashion. Tolkien himself was naturally delighted to be feted by an American university librarian who had substantial funds to back up his praise of the author's literary output. Although a major Tolkien collection has subsequently been developed by the Bodleian Library in Oxford, all serious Tolkien scholars know that they will have to spend a considerable amount of research time in Milwaukee.

Another example of the careful cultivation of an author, with the greatest respect for their circumstances, is presented by the papers of Chinua Achebe held by Harvard University. Regrettably, it has been and remains the case that, despite its extraordinarily rich literary culture, Nigeria has no history at all of collecting literary manuscripts (Sutton, 2016). The authorities at Harvard, seeing a great opportunity in this lacuna, were able to establish an excellent working relationship with Achebe himself, inviting him and (importantly) his family to Harvard, according him appropriate honour and respect, formally and informally, and in due course acquiring the whole of his personal archive. While some of his professional papers and correspondence are to be found in other institutions, notably his papers in connection with 
the Heinemann African Writers series, which are in the University of Reading Library in England, anyone who wishes to study the man described by his fellow Nigerian Ezenwa-Ohaeto as "the father of modern African writing" will expect to conduct much of their primary research in Cambridge, Massachusetts.

The case of Carlos Fuentes and his literary papers in the Firestone Library at Princeton University is more complex and more controversial. Mexico does have a strong tradition of collecting literary papers and respecting its own literary culture. It does not, however, have institutions which are well funded or well placed to make these sorts of high-profile acquisitions. As a writer who saw himself as a citizen of the world as well as a citizen of Mexico (the colophon to his novel La Campaña, for example, indicates that it was written in Berlin, Madrid, Cornwall and Argentina), Fuentes had no problem about selling his archive to an institution which would pay him very well for it and which had a strong reputation for its custodianship of the archives of Latin American authors. In Mexico, however, this particular acquisition by Princeton was widely seen as an imperialist outrage, and phrases such as "cultural theft" and "wholesale appropriation of literary patrimony" were used (Leovy, 2001).

A more neutral diasporic example is the story of how the papers of Ernest Hemingway arrived in the John F. Kennedy Presidential Library and Museum. On Hemingway's death in 1961, most of his papers remained in his house in Cuba. With the improbable combined assistance of President Kennedy and the Cuban Prime Minister (later President) Fidel Castro, Mary Hemingway was enabled to travel to Cuba and to retrieve the papers. In exchange, she donated the Hemingway family home, the Finca Vigía, to the people of Cuba. In 1962 Mrs. Hemingway was deeply moved by the honour paid to her late husband at a dinner at the White House and by the continuing attention of President and Mrs. Kennedy. After the President's assassination, it was an understanding reached between the two widows, Mrs. Hemingway and Mrs. Kennedy, which brought the Ernest Hemingway Collection to the John F. Kennedy Presidential Library.

In general, as would have been expected, the movement of diasporic literary archives was found to be from poorer countries to richer countries, but with this general truth being modified in ways that were highly dependent on the language used by individual writers. While literary manuscripts in English by authors from countries such as Nigeria, Trinidad and Tobago, and Jamaica would be actively collected by well-funded institutions in the USA, Canada and (rather later) Britain, literary manuscripts in other languages might be virtually ignored. The major market in the USA was, and remains, for manuscripts in the two principal languages of that country, English and Spanish. The archives of Nobel Prize-winning authors such as José Saramago (mostly in Portuguese), Orhan Pamuk (mostly in Turkish) or Elfriede Jelinek (mostly in German) had much less market attraction in North America than the papers of authors who had written in English or Spanish. As a result Saramago's papers are almost all, appropriately, in Lisbon and Jelinek's papers are almost all in Vienna. A country like Brazil, with a proud literary culture and a wide range of institutions collecting literary papers, had experienced very little competition in the 
acquisition of literary archives, principally because the papers were almost all in the Portuguese language.

One surprising example of what might be regarded as "reverse diasporism"an English-language author whose papers have ended up in Spain-is provided by the satirical comic author Tom Sharpe, whose archive arrived in the Universitat de Girona in 2015. Sharpe had lived in Catalonia for many years, although he notoriously refused to learn either Spanish or Catalan. In his will he left all his literary archive to Doctor Montserrat Verdaguer and she in turn passed them on to the university in Girona, which has a very strong and varied collection of literary papers, but is not the first place where one would expect to look for the manuscripts of the Porterhouse Blue and Wilt novels.

A final example, in this section, brings us closer to the primary meaning of "diaspora," and forms part of the expanding work on "archival safe havens" in which the Network has fully participated. The archive of the Syrian poet Ali Ahmad Saïd Esber, known by the splendid cognomen of Adonis, has been acquired and housed at the Institut Mémoires de l'édition contemporaine (IMEC) in Caen, where it has a place of honour alongside the archives of Jean Genet, Louis Althusser, Irène Némirovsky, Michel Foucault, and Erik Satie (see the essay by André Derval below). While the exact terms of the deposit are not in the public domain, it has been widely reported that the acquisition was a form of safeguarding of literary heritage and left open the possibility of a return of the archive to Syria at a time when its safety and the safety of its rights-owners there could be assured.

In establishing the Diasporic Literary Archives Network our idea was to explore the implications of improbable and unpredictable archival locations, such as: the power of the market, imbalances between richer and poorer countries, the power of serendipity, and the magical attractiveness and collectability of literary manuscripts themselves. The intention was not to indulge in lamentations, in the style of Philip Larkin and others, about the loss of UK heritage materials to wealthy North American institutions with no apparent ethical collecting policy, but rather to formulate a set of definitions and truths about literary manuscripts and literary correspondence and then to look at desirable actions, activities, and acts of solidarity.

What I have elsewhere called "the Larkin trap" should by now be regarded as a historical attitude formed in the 1960s and 1970s by admirers of Philip Larkin and of his dismal and pessimistic essay "A Neglected Responsibility: Contemporary Literary Manuscripts." The futility of this approach, and its whingeing wistfulness, in the digital 2010s ought to be self-evident:

In talking about locations of literary manuscripts, we always need to be aware of the "Larkin trap." This involves falling into the Eeyore-like gloom and pessimism which Philip Larkin regularly manifested when talking about literary papers-usually spiced with a carping tone of anti-Americanism. 
Commentators who fall into the "Larkin trap" have two main laments: first, that virtually all modern British and Irish literary manuscripts have been acquired by US institutions; and second, that this is a disaster for scholarship. The crude overstatement of these laments is more of a hindrance than a help to those of us who work to emphasize the importance of literary manuscripts and their key place in our own cultural heritage, and who want to encourage international cooperation.

Sutton, 2010

Larkin was simply wrong about the collecting of literary manuscripts in Britain and Ireland in the 1960s and 1970s (Sutton, 1985 and 1987). In particular, he seems to have had no awareness of the fine literary collections which were beginning to develop in the National Library of Scotland, the National Library of Ireland, and the National Library of Wales. Certainly, there had been many dramatic acquisitions of British literary collections by institutions in the USA and Canada, but less wellfunded institutions in the British Isles were nonetheless quietly and determinedly building important literary collections. As the Location Register of Twentieth-Century English Literary Manuscripts and Letters concluded its first round of research in the late 1980s, it had identified over 400 British and Irish institutions holding some literary papers, including, of course, the University of Hull's own collections (now held in Hull History Centre).

Moreover, as has frequently been pointed out, representatives of a country which has repeatedly found pretexts not to return the Elgin Marbles to Greece nor the looted Egyptian treasures of the British Museum to Cairo are poorly placed to claim any moral high ground in respect of North American acquisition of British literary manuscripts.

It was important for the emerging Network to engage with other languages and other continents. The recruitment of partners from France, Italy, Namibia, Trinidad and Tobago, and the United States made possible a much wider and more varied set of perspectives than had been usual in previous literary and archival research partnerships, and the Caribbean and African perspectives within the Network were to prove particularly original and enriching.

In a series of five international workshops, beginning in 2012, the Network explored its chosen themes, with the workshops headlined as follows:

1) Questions informing scattered legacies: an introduction to the ideas of diasporic literary manuscripts (at the University of Reading, June 2012).

2) Examining split collections (at the Centro per gli studi sulla tradizione manoscritta di autori moderni e contemporanei, Pavia, February-March 2013).

3) The stakes of public/private ownership: including the ways in which literary manuscripts are represented in business, publishing and other non-literary 
collections (at the Institut Mémoires de l'édition contemporaine, Caen, May 2013).

4) The politics of location: a workshop on sensitive issues of acquisition, including the "loss" by less wealthy countries of their archival literary heritage (at the National Library of Trinidad and Tobago, Port of Spain, March 2014).

5) Diaspora and possibilities for digitization (at the Beinecke Rare Book and Manuscript Library, Yale University, October 2014). This was a meeting which covered some of the exciting new initiatives which are opening up in respect of born-digital and digitized archives, especially in richer countries, but also explored some of the more controversial areas for poorer countries-not only as regards technological problems, but also issues relating to equalities, human rights, and the politics of purchasing power.

Reports on these workshops can be found on the Diasporic Literary Archives website, and many of the presentations can be viewed in an unedited state (sometimes embarrassingly so) on YouTube.

Some conclusions emerged more strongly than had been anticipated. The theme of "split collections," for example, came to be seen as really central to all discussion of archival research in literature and the nature of literary manuscripts. This aspect of our diaspora attracted considerable critical attention:

Literary archives, then, tend to travel much further than other types of papers and to be housed in unpredictable locations-often in locations determined by market forces rather than by internal archival logic-making the work of literary researchers more complex, more dependent upon careful research travel plans, and often more expensive. This situation is compounded by the way that literary papers are usually found, for any one author, to be divided between several collecting institutions. This phenomenon, which we have come to call "split collections," will be familiar to most literary researchers. My own university in Reading has an outstanding collection of papers of Samuel Beckett, but it is a collection which can only make archival sense by constant cross-referencing to the Beckett holdings in Trinity College Dublin and the Harry Ransom Center in Austin, Texas. In 2013 at a workshop in Pavia, Italy, Michael Forstrom of Yale's Beinecke Library gave a very complete description of the ways in which literary collections can be "split." Forstrom identified for his Diasporic Literary Archives audience no fewer than fourteen ways in which literary fonds might be divided:

- Split between different collecting repositories;

- Split between fonds and what survives;

- Split by collecting strategy or agreement;

- Split between early portion of papers and (living) creator;

- Split by relocation and change in custody; 
- Split between collected portion of papers and component in private hands;

- Split by provenance: papers versus artificial collection;

- Split by accession(s);

- Split within institutions;

- Split between personal, professional, and family papers;

- Split between papers and media;

- Split between papers and born-digital;

- Split by reproduction;

- Split between collection(s) and national interest.

"Split collections" represent an essential part of the world of literary manuscripts. We are starting to see a small number of digitization projects which are able to bring split collections back together again (such as the online Shelley-Godwin archive), but these remain rare and special (well-funded) cases.

Sutton, 2016

Scholars, editors and critics commenting on the workshops stressed the difficulties that split collections brought to their work. Typical examples from the published volumes of the original UK Location Register had emphasized the scale of the problem, in its brief descriptions of collections outside the British Isles:

GRAVES, Robert, 1895-1985 There are five large collections of papers of Robert Graves in North American libraries: Lockwood Library, State University of New York at Buffalo-Southern Illinois University Library-Humanities Research Center, University of Texas at Austin-University of Victoria Library, British Columbia-University of San Francisco Library

KIPLING, Rudyard, 1865-1936 There are collections of Rudyard Kipling papers in the following North American libraries: Houghton Library, Harvard University-Cornell University Library-Humanities Research Center, University of Texas at Austin-Rosenbach Foundation, Philadelphia-Library of Congress-Syracuse University Library-Bancroft Library, University of California at Berkeley-Berg Collection, New York Public Library

RUSKIN, John, 1819-1900 The major collections of Ruskin manuscripts and letters outside the United Kingdom are in the Beinecke Rare Book and Manuscript Library, Yale University and the Pierpont Morgan Library, New York. There are also Ruskin papers in the following North American libraries: Humanities Research Center, University of Texas at Austin-Henry E. Huntington Library, San Marino, California-Princeton University Library-Rosenbach Foundation, Philadelphia-Houghton Library, Harvard University—Berg Collection, New York Public Library-Boston Public Library-Columbia University Library-McGill University Library, Montreal-University of Arizona Library-Duke University Library_Library of Congress (Sutton, 1988) 
Building on this early work, the Network's own website now includes a set of pages headed "Diasporic Collections," illustrating the international scale and span of split literary collections from many other countries, languages and literary cultures.

At the Network's first workshop, the Kafka archive, whose ownership is shared by the Bodleian Library in Oxford and the Deutsches Literaturarchiv in Marbach, came under close scrutiny as one possible way of avoiding split collections. The conclusion, however, was that, while fascinating, the Bodleian-Marbach cooperation was unlikely to be a model for the future which would be widely followed.

While the "hub" of the Network was scholarly and archival work on the diasporic nature of literary manuscripts, a number of "spoke" projects developed as the Network's wide-ranging workshops explored related issues. As the Network brought in a rich variety of experts from around the world, a number of unforeseen work-programmes evolved, notably joint work with UNESCO and PEN International on "archives at risk"; joint work with swisspeace and UNESCO on "archival safe havens"; and joint work with the Society of Authors and the National Archives on creating guidance for authors considering disposing of their personal archives.

The work on archives at risk began in a francophone context, from the work already begun by the Network's IMEC and ITEM partners (Institut Mémoires de l'édition contemporaine and Institut des textes et manuscrits modernes), but also drew upon good working relations with the Endangered Archives Programme, based at the British Library (see the essay by Jens Boel below). It quickly became clear that there were numerous projects, actual and proposed, mostly based in Europe, working devotedly and altruistically on ways of saving endangered archives and the archives of dissident authors and developing proposals on archival safe havens. Some of these proposals were presented in 2014 on behalf of the Network to the governance bodies of the International Council on Archives, where they caused some controversy and concern. It was clear to the core members of the Network that all of this work needed to be brought together under a single validating umbrella organization (the obvious candidate being UNESCO), probably with another organization providing the office support and driving the project forward. This model finally began to take shape in 2017, with UNESCO in the validating role; swisspeace (a wonderful partner organization, a "practice oriented peace research institute," based in Bern) in the dynamic organizing role; and the Diasporic Literary Archives Network playing a facilitating role.

The Network's commitment to working with professional colleagues in the Caribbean region and in eastern and southern Africa has been sustained. From the acquisition of the Monique Roffey Archive by the University of the West Indies (St. Augustine) in 2014 to the acquisition of the Anthony C. Winkler Archive by the National Library of Jamaica in 2017, the Network has played another facilitating role which has been generously acknowledged by our Caribbean partners.

The work with colleagues in the National Archives of Namibia, described in Chapter 6, was very consciously designed as a template which could be adopted and 
adapted by other colleagues and partners in the region. The working assumption has been that every country with a strong literary tradition owes it to itself to develop a strong tradition of collecting literary manuscripts as well. Best-practice models have been publicized by the Network and by the Section for Archives of Literature and Art (SLA) within the International Council on Archives, and range as widely as Brazil, Uruguay, Finland, Austria, France, South Korea, and Hong Kong.

A significant output from work begun by the Network was a document entitled Authors and Their Papers, ${ }^{1}$ jointly created with representatives of the Society of Authors, the National Archives, and the Group for Literary Archives and Manuscripts (GLAM). The document assumes that many literary authors are interested in the eventual disposal of their personal archive, but have little idea of the practicalities which might be involved. It provides a step-by-step guide for authors, under headings such as "Rationale"; "What to keep"; "How to keep it"; "Transferring papers to an archives service: gift, bequest, permanent loan or deposit"; "Sale of papers and archives"; "Valuation"; "Offsetting value"; "Terms of transfer: storage"; "Terms of transfer: copyright"; "Terms of transfer: digitisation"; and so on.

The identification of the characteristic problem of split collections was a fascinating exercise, full of delightful anecdotes and strange puzzles and mysteries, but the Network is determined that it should lead on to work on best-practice protocols for sharing and cooperating with collections in the best interests of archival researchers. Clearly in the digital era, there are already more options for cooperation than there were in the past, and the likely development of collecting born-digital literary archives at some future time and storing them in "the cloud" opens up the intriguing possibility of a literary archive having two permanent homes, not following the Bodleian-Marbach Kafka model of an archive regularly in transit, but rather a stored and searchable digital archive which could be simultaneously fully available in two countries (say, Mexico-USA; Namibia-South Africa; or Jamaica-UK).

Discussion about digital futures in respect of literary archives has formed an important, if necessarily thus far inconclusive, part of the Network's deliberations. An early shock, at the very first workshop in 2012, was to receive the clearest possible expert opinion that in the present decade the valuation of digital literary collections is largely based on guesswork and hoping for the best. In the case of hybrid paper and born-digital archives, the paper component would be carefully valued and then a notional sum added on for the digital part. The absence of valuation criteria derives from an absence of precedents; an absence of information about likely users; an absence of a private market for archives in this format; and a certain lack of trust in the verifiability of the digital archive. If an author deposits a copy of a hard disk, rather than the hard disk itself, as seems to be happening in the majority of cases, how will the purchaser be able to assess what has been removed before deposit? Thus while the future value of email collections is absolutely certain (and from a biographer's perspective the two-way nature of email threads can

I Available at http://glam-archives.org.uk/?p=1726, and as Appendix 1 to this volume. 
make them much more useful than traditional correspondence collections), the future value of born-digital literary manuscripts remains a matter of speculation and uncertainty.

At the conclusion of the fifth workshop of the Diasporic Literary Archives Network, at the Beinecke Library, Yale University, in November 2014, there was agreement by general acclaim that the Network should seek to continue its work and its partnerships into the future. The present volume and the Diasporic Literary Archives Network website reflect that continuity.

Examples of future work-programmes for the Network (say from 2018 to 2025) would potentially include:

- "Archives at risk": new protocols for collaboration on endangered collections worldwide (working with UNESCO and swisspeace);

- "Archival safe havens": a subset of archives at risk: cases of archives in extreme danger which may, as a last resort, be physically moved to a safe location or be digitally copied and the copies transferred to a trusted repository;

- The dispersal of literary papers through publishing and business archives;

- Protocols for collaboration between repositories with "split collections;"

- Mapping split collections: a cartographic approach;

- The diaspora of digital literary archives: best practice and digital solutions;

- The literary archives of Namibia: a case study and model for other African countries;

- Caribbean archives in Caribbean institutions: a new future;

- "Hidden archives": the uncatalogued troves: locating uncatalogued collections and finding shared solutions;

- Further work with the Society of Authors, the National Archives and the Group for Literary Archives and Manuscripts (GLAM) on guidance and encouragement for literary authors in respect of their personal archives;

- Locations of literary collections: creation of a world-wide list (joint work with the International Council on Archives' (ICA) Section for Literary Archives);

- Examples of diasporic literary collections: maintenance of an online database.

This exciting and diverse range of ongoing and future projects will keep the Diasporic Literary Archives Network itself active into the 2020s, and it is hoped that a good number of them will be adopted by other funders or consortia, by some or all of the existing six partners, or by the Section for Archives of Literature and Art (SLA) within the International Council on Archives.

The essays which follow illustrate the wide range of ideas, projects, and actions which came together under the rubric of "diasporic literary archives" and derived from the activities and meetings of the Network. Since the Network's inception, it has welcomed the development of its diasporic concept by other research teams and projects, both related and unrelated to the Network itself. It seems clear that the original premise has already become mainstream in the world of literary archives, 
and the essays collected here constitute a first book-length report on work-inprogress but also in many cases provide ways of looking ahead to future research and future projects.

\section{Bibliography}

Authors and Their Papers: A Guidance Sheet for Authors and Writers. Available at http://glam-archives.org.uk/?p=1726, and as Appendix 1 to this volume.

Baker, Fran, Jessica Gardner, Chris Sheppard, and David C. Sutton. "Magical and Meaningful: Thirty Years of Literary Manuscripts Collecting in the UK and Ireland." Archives 122 (2010): 21-27.

Diasporic Literary Archives Network. www.diasporicarchives.com.

Ezenwa-Ohaeto. Chinua Achebe: A Biography. Oxford: James Currey, 1997.

Leovy, Jill. "Mexican Scholars Lament the Loss of Writers' Archives to U.S." Los Angeles Times, February 25, 2001. Part A, 3.

Location Register of English Literary Manuscripts and Letters website. University of Reading. www.locationregister.com.

Location Register of Twentieth-Century English Literary Manuscripts and Letters.

Edited by David C. Sutton. 2 vols. London: British Library, 1988.

Sutton, David C. "A Highly Original Paper Chase: Tracking Down Modern Literary Manuscripts and Letters in British Universities." Times Higher Education Supplement, April 5, 1985, 13.

—_. "Seeking Out Literary Papers." The Author (Summer 1987): 43-44.

- "Securing the Nation's Literary Heritage: Report." AMARC Newsletter 55 (2010): 9-11.

—_ ."Literary Archives for Ever (?)” ARC Magazine 261 (2011): 17.

"The Destinies of Literary Manuscripts: Past, Present and Future." Archives and Manuscripts 42 (2014): 295-300.

—_ "The Diasporic Literary Archives Network and the Commonwealth: Namibia, Nigeria, Trinidad \& Tobago, and other examples." New Review of Information Networking 21 (2016): 37-51.

swisspeace. www.swisspeace.ch. 